\title{
Kreatifitas Merangkai Bunga Kering bagi Ibu-Ibu PKK Perumahan Bungo Bumi Indah Kelurahan Bungo Pasang Kecamatan Koto Tangah Kota Padang
}

\author{
Wati1 $^{1}$, Deltri Apriyeni' ${ }^{2}$, Meri Rahmania ${ }^{2}$ Nazirwan $^{3}$, Indro Saputro ${ }^{1}$ \\ 1 Program Studi Pendidikan Akuntansi, STKIP PGRI Sumatera Barat, Jl. Gn. Pangilun, Padang, 25173. Indonesia \\ ${ }^{2}$ Program Studi Pendidikan Ekonomi, STKIP PGRI Sumatera Barat, Jl. Gn. Pangilun, Padang, 25173. Indonesia \\ 3Jurusan Administrasi Negara, STIA Adabiah Padang, Jl. Jati Adabiah No. 1 Padang, 25159. Indonesia \\ E-mail: tegowati73@gmail.com
}

Keywords:

creativity, dried

flowers,

entrepreneurial soul

Kata Kunci:

bunga kering, kreatifitas, jiwa wirausaha

\begin{abstract}
Based on the development program, the goal to be achieved is to shape individuals and communities to become independent. This independence includes the independence of thinking, acting, and controlling what they do. From observations made, there are PKK members who only act as housewives. Though they can earn money to support their family income. As a solution, they need to get proper training conducted by the local government, service programs, or certain other institutions. In line with this PKM activity, there will be training and fostering creativity for PKK members through the use of dried grains into various dried flower creations. This activity was began with communicate by local PKK management. The presentation of the material was done by the method of lectures and discussions. Furthermore, training and practice directly make dried flowers with materials that have been prepared by the service team. To motivate participants to be more creative and uplifting, the dedication team presented a ready-made example. It hopes that participants will gain useful skills and eventually become creative and skilled human beings to increase family income.
\end{abstract}
ABSTRAK
Terkait dengan program pembangunan, bahwa tujuan yang ingin dicapai adalah untuk membentuk individu dan masyarakat menjadi mandiri. Kemandirian tersebut meliputi kemandirian berpikir, bertindak dan mengendalikan apa yang mereka lakukan. Dari pengamatan yang telah dilakukan terdapat ibu-ibu anggota PKK yang hanya berperan sebagai ibu rumah tangga saja. Padahal mereka dapat berpartisipasi mencari nafkah untuk menambah penghasilan keluarganya. Sebagai solusinya mereka perlu mendapatkan pelatihan-pelatihan baik yang diadakan oleh pemerintah daerah setempat, program pengabdian, atau lembaga tertentu lainnya. Sejalan dengan kegiatan PKM ini akan dilakukan pelatihan dan pembinaan kreatifitas terhadap ibu-ibu anggota PKK melalui pemanfaatan biji-bijian kering menjadi aneka kreasi bunga kering. Kegiatan ini diawali dengan pengurusan ijin serta koordinasi dengan pengurus PKK setempat. Penyajian materi dilakukan dengan metode ceramah, diskusi, dan tanya jawab. Selanjutnya pelatihan dan praktek secara langsung membuat bunga kering dengan bahan-bahan yang telah disiapkan oleh tim pengabdian. Untuk memotivasi peserta agar lebih kreatif dan semangat, maka tim pengabdian menampilkan contoh yang telah jadi. Melalui program PKM ini diharapkan peserta akan mendapatkan ketrampilan yang bermanfaat akhirnya menjadi manusia yang kreatif dan terampil sehingga dapat menambah pendapatan bagi keluarga. 


\section{PENDAHULUAN}

Pemberdayaan terhadap masyarakat pada dasarnya harus dilaksanakan secara optimal dan terarah agar dapat memperbaiki keadaan ekonomi sekaligus mampu mengangkat kondisi ekonomi masyarakat yang ada. Dengan memberikan kewenangan dan kekuatan kepada masyarakat untuk mengakses sumber daya ekonomi yang tersedia secara optimal, diharapkan masyarakat dapat berdaya dalam memperbaiki kemampuan ekonominya, sehingga mereka dapat memenuhi kebutuhan dasar mereka secara mandiri.

Terkait dengan program pembangunan, bahwa tujuan yang ingin dicapai adalah untuk membentuk individu dan masyarakat menjadi mandiri. Kemandirian tersebut meliputi kemandirian berpikir, bertindak dan mengendalikan apa yang mereka lakukan. Kemandirian masyarakat merupakan suatu kondisi yang dialami oleh masyarakat yang ditandai dengan kemampuan memikirkan, memutuskan serta melakukan sesuatu yang dipandang tepat demi mencapai pemecahan masalah-masalah yang dihadapi dengan mempergunakan daya kemampuan yang dimiliki (Widjajanti, 2011).

Seseorang yang tidak memiliki jiwa kemandirian, segala perilakunya akan bergantung pada pihak lain. Kebergantungan menyebabkan mereka tidak dewasa, manja serta tidak mau berusaha keras, sehingga inovasi dan kreativitasnya tidak berkembang. Sebaliknya seseorang yang memiliki jiwa kemandirian akan muncul pada diri mereka sikap percaya akan kemampuan diri, berani memfaatkan peluang, tidak takut gagal dan selalu bekerja keras, ulet serta kreatif (Sukidjo., 2012).

Wijatno (2009) mendefenisikan entrepreneurship sebagai aktivitas untuk menciptakan sesuatu yang baru. Sedangkan Hendro (2011) menjelaskan bahwa entrepreneurship adalah suatu kemampuan untuk mengelola sesuatu yang ada dalam diri anda untuk dimanfaatkan dan ditingkatkan agar lebih optimal (baik) sehingga bisa meningkatkan taraf hidup anda di masa mendatang. Saiman (2014) menyatakan kewirausahaan adalah hal-hal atau upaya-upaya yang berkaitan dengan penciptaan kegiatan/usaha/aktivitas bisnis atas dasar kemauan sendiri. Tujuan akhir dari proses pemberdayaan masyarakat ini adalah agar mereka bisa mandiri sehingga dapat meningkatkan taraf hidup keluarga dan mengoptimalkan sumberdaya yang dimilikinya. Melalui pemahaman jiwa entrepreneurship, diharapkan mereka bisa mencoba berusaha mandiri dengan melihat berbagai peluang yang ada di sekeliling mereka. Sesuai dengan potensi daya/kekuatan yang mereka miliki. Sementara Suparyanto (2013) mengatakan bahwa motivasi sebagian besar penduduk Indonesia untuk berwirausaha relatif rendah. Memiliki profesi menjadi seorang wirausahawan pada umumnya merupakan satu pilihan terakhir, yang sifatnya hanya sementara. Untuk menumbuhkembangkan jiwa wirausaha perlu dukungan dari berbagai pihak, termasuk pihak pemerintah, badan usaha, kalangan cendikiawan, dan unsur masyarakat.

Kecamatan Koto Tangah merupakan kecamatan terluas diantara 11 kecamatan yang ada di Kota Padang. Luas wilayahnya sekitar 232,25 km² yang terdiri dari 13 kelurahan. Kelurahan Bungo Pasang merupakan salah satu kelurahan yang ada di kecamatan Koto Tangah, yang memiliki luas 3,32 km², dan jarak kelurahan Bungo Pasang ke kecamatan Koto Tangah sekitar 6 km, ke Kota Padang 9 km, dan Provinsi 8 km. Memiliki 16 Rukun Warga (RW) dan 52 Rukun Tetangga (RT). Jumlah penduduknya 12.256 jiwa, terdiri dari laki-laki 6.118 jiwa dan perempuan 6.138 jiwa (BPS Kota Padang, 2018).

Salah satu RT/RW yang ada dikelurahan Bungo Pasang adalah RT 001/RW 012 yang memiliki sekitar 106 Kepala Keluarga (KK), berjumlah sekitar 400 jiwa yang tinggal di dalam komplek Perumahan Bungo Bumi Indah. Dengan profesi pekerjaan yang berbeda-beda, dari pengamatan yang telah dilakukan ada sebagian ibu-ibu yang tidak bekerja, artinya hanya berperan sebagai ibu rumah tangga saja. Padahal selain berperan sebagai ibu rumah tangga, 
mereka juga bisa berperan atau ikut berpartisipasi mencari nafkah untuk pemenuhan ekonomi keluarganya.

Berdasarkan permasalahan inilah maka kami memberikan pengarahan dan pelatihan tentang kreatifitas pembuatan bunga kering sebagai usaha menumbuhkan jiwa wirausaha IbuIbu anggota PKK Perumahan Bungo Bumi Indah Kelurahan Bungo Pasang, Kecamatan Koto Tangah, Kota Padang. Sehingga mereka mampu membuat suatu hasil karya yang memiliki nilai jual, dengan harapan bisa menambah pendapatan bagi keluarga. Bunga kering ini dapat tercipta dengan indahnya karena adanya sentuhan tangan-tangan terampil yang memanfaatkan bijibijian kering dan rempah-rempah kering sebagai bahan dasarnya.

Permasalahan yang dihadapi oleh ibu-ibu anggota PKK Perumahan Bungo Bumi Indah Kelurahan Bungo Pasang diantaranya adalah:

1. Terbatasnya pengetahuan mengenai cara memanfaatkan biji-bijian kering dan rempahrempah kering menjadi hiasan cantik bunga kering yang memiliki nilai jual.

2. Terbatasnya pemahaman untuk mendapatkan pendapatan tambahan sebagai salah satu usaha meningkatkan ekonomi keluarga dengan cara yang sederhana, mudah dan tepat guna.

3. Ketidaktahuan ibu-ibu anggota PKK bahwa mereka bisa menciptakan usaha dengan keterampilan dan kreatifitas yang dimilikinya.

Tujuan dari kegiatan pengabdian ini adalah agar ibu-ibu anggota PKK Perumahan Bungo Bumi Indah dapat:

1. Meningkatkan kefahaman mengenali potensi diri.

2. Mengembangkan potensi diri untuk memanfaatkan biji-bijian kering menjadi aneka kreasi bunga kering.

3. Meningkatkan ketrampilan dan menumbuhkan jiwa kewirausahaan.

4. Menumbuhkan kreatifitas diri yang akhirnya menjadi manusia yang kreatif dan terampil.

Manfaat dari kegiatan ini adalah agar ibu-ibu anggota PKK Perumahan Bungo Bumi Indah mampu:

1. Memanfaatkan biji-bijian kering dan rempah-rempah kering menjadi aneka kreasi bunga kering yang cantik.

2. Membuat bunga kering sebagai hiasan rumah yang memiliki nilai jual.

3. Menambah pendapatan keluarga.

\section{METODE}

Kegiatan pengabdian ini dilaksanakan di Perumahan Bungo Bumi Indah RT 001/RW 012, dengan pesertanya adalah ibu-ibu anggota PKK yang berjumlah sekitar 25 orang yang aktif, acara arisan bulanan merupakan acara rutin yang setiap bulan dilaksanakan. Untuk itu kami dari tim pengabdian memanfaatkan momen acara arisan tersebut untuk kegiatan pengabdian, yang sebelumnya kami telah berkoordinasi dengan pengurus PKK setempat. Untuk mendukung realisasi program pengabdian ini dilakukan tahapan kegiatan sebagai berikut:

1. Penulisan materi tentang bagaimana cara membuat bunga kering berbahan dasar biji-bijian kering dan rempah-rempah kering

2. Penyajian materi berdasarkan metode ceramah, diskusi dan tanya jawab.

3. Memberikan contoh bunga kering yang sudah jadi, sehingga menjadi daya tarik bagi peserta kegiatan.

4. Pelatihan dan pembuatan secara langsung bunga kering, yang sebelumnya tim pengabdian sudah mempersiapkan bahan-bahannya.

5. Pendampingan pada program pengabdian berkelanjutan dilakukan terhadap peserta yang mengalami kesulitan dalam proses pembuatannya. 
Bahan yang digunakan untuk membuat bunga kering ini adalah biji-bijian kering yang mudah didapatkan di sekitar kita dan rempah-rempah kering yang biasa digunakan untuk bumbu masak. Bahan-bahan tersebut adalah seperti berikut ini:
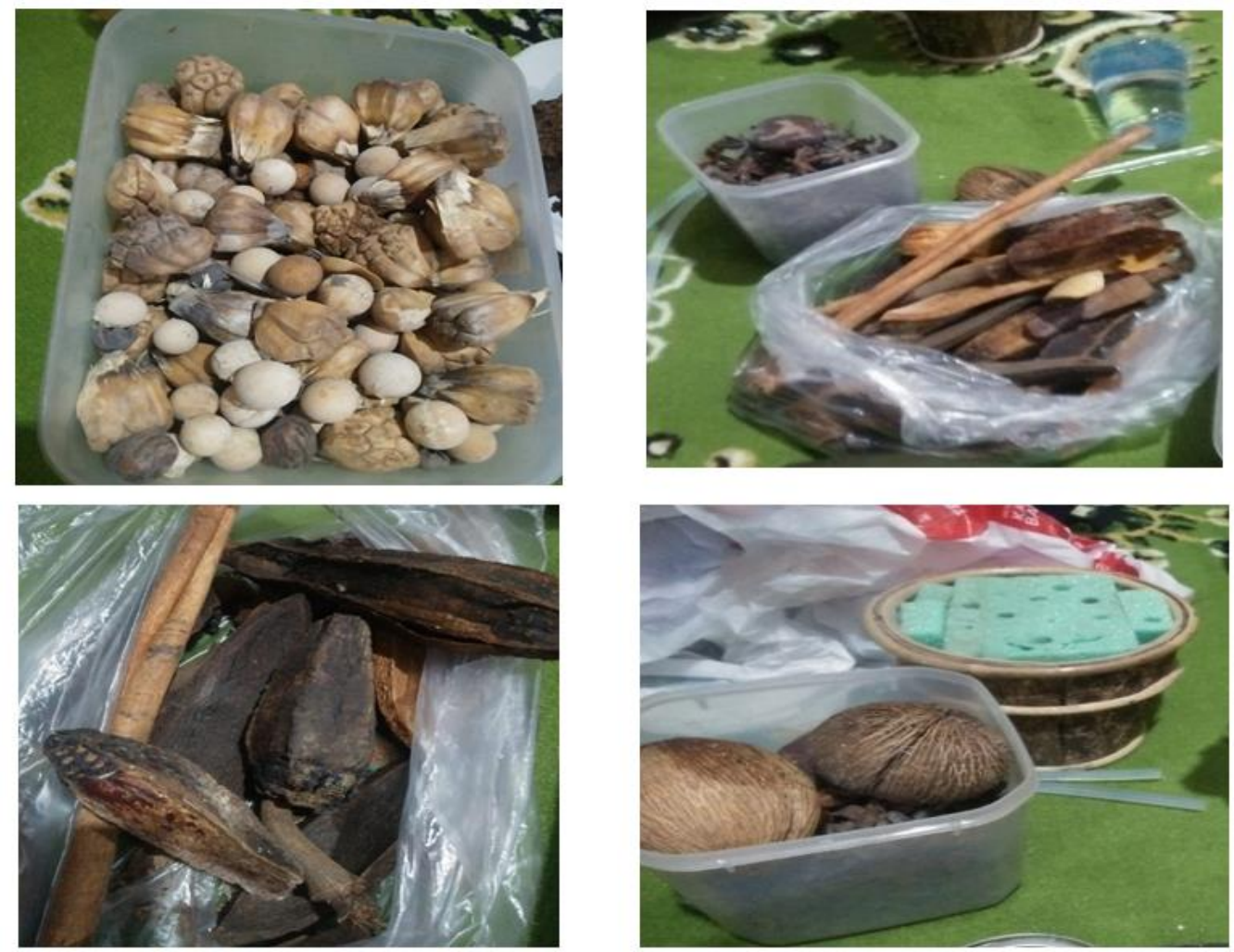

Gambar 1. Bahan dasar pembuatan bunga kering

Alat yang digunakan untuk membuat bunga kering ini juga sangat sederhana dan mudah mendapatkannya seperti lem tembak, kuas, tiner dan vernis.
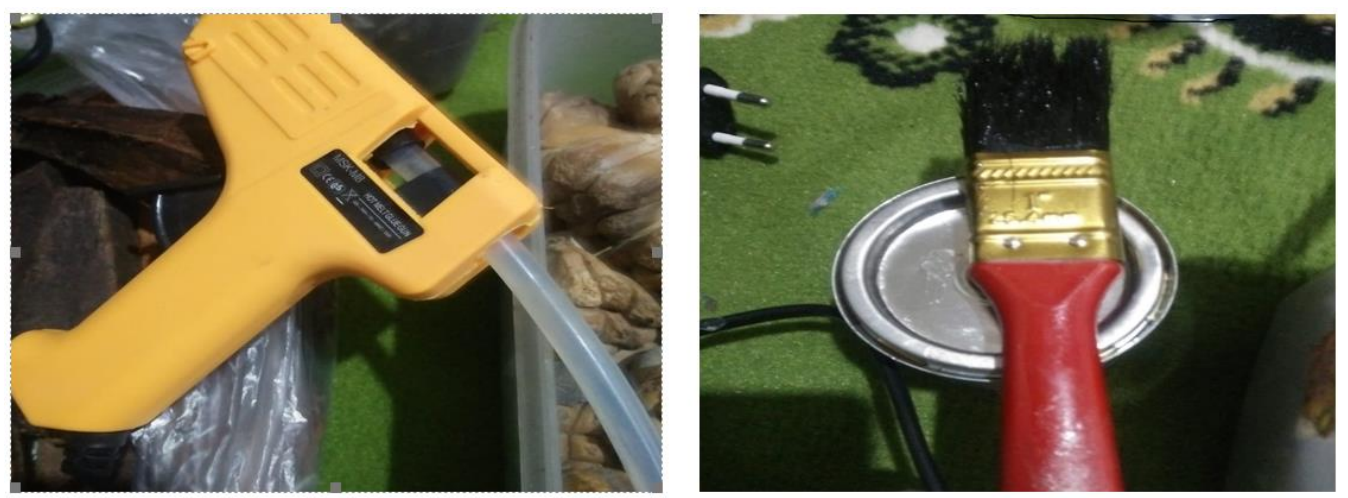

Gambar 2. Alat yang digunakan untuk membuat bunga kering

Untuk mencapai tujuan program pengabdian ini, tim pelaksana menggunakan pendekatan pemecahan masalah (Problem solving) yang meliputi analisis situasi, perumusan masalah secara spesifik, penentuan prioritas masalah, penentuan tujuan, memilih alternatif terbaik dan menguraikannya menjadi rencana operasional, melaksanakan rencana kegiatan. 


\section{HASIL DAN PEMBAHASAN}

Kegiatan pengabdian kepada masyarakat tentang kreatifitas merangkai bunga kering bagi ibu-ibu anggota PKK Perumahan Bungo Bumi Indah Kelurahan Bungo Pasang ini telah selesai dilaksanakan oleh Program Studi Pendidikan Akuntansi dan Program Studi Pendidikan Ekonomi STKIP PGRI Sumatera Barat serta Jurusan Administrasi Negara STIA Adabiah Padang. Tim pelaksana kegiatan sebanyak 5 orang, yang terdiri dari 3 orang dosen dari kampus STKIP PGRI Sumatera Barat, 1 orang dosen dari STIA Adabiah Padang dan dibantu oleh 1 orang mahasiswa dari Program Studi Pendidikan Akuntansi STKIP PGRI Sumatera Barat.

Kegiatan pengabdian ini dilaksanakan selama 1 hari kegiatan, yang diikuti oleh sekitar 25 orang peserta arisan ibu-ibu PKK RT 001, RW 012, Kel. Bungo Pasang, Kec. Koto Tangah. Kegiatan pelatihan bertempat di rumah ibu Elly yang beralamat di Komplek Bungo Bumi Indah Blok A No. 2. Materi pelatihan disampaikan oleh salah satu tim pengabdian yaitu ibu Dr. Deltri Apriyeni. Setelah itu dilanjutkan dengan mempraktekan langsung bagaimana cara membuat bunga kering dari biji-bijian kering, bahkan terdapat bijian yang memang terbuang begitu saja di pinggir jalan yang dapat dimanfaatkan seperti biji buah mahuni, dan lain sebagainnya. Pada saat praktek seluruh tim ikut aktif membimbing dan memandu peserta sehingga mereka dapat mengikuti pertahapan proses merangkai bunga kering yang cantik dengan baik.

Selama proses pelatihan pembuatan bunga kering peserta ibu-ibu PKK ini sangat antusias memperhatikan dengan seksama. Banyak dari kalangan mereka yang tidak mengetahui bagaimana cara membuat bunga kering tersebut, padahal sangat mudah dan hanya memerlukan waktu antara satu hingga dua jam saja untuk menyelesaikannya. Disela-sela masa istirahat setelah menyelesaikan pekerjaan rumah, mereka dapat membuatnya. Minimal, walaupun tidak untuk dijual bunga kering tersebut dapat dimanfaatkan untuk pajangan rumah sendiri.

\section{Proses Pembuatan}

Proses pembuatannya sangat mudah, tidak terikat oleh aturan yang baku, cara meletakkan bijian dan rempah-rempah kering berdasarkan inisiatif sendiri, yang penting hasil akhirnya menjadi susunan bunga kering yang cantik dan indah. Proses pembuatan tersebut dapat dilihat pada gambar 3 berikut ini:
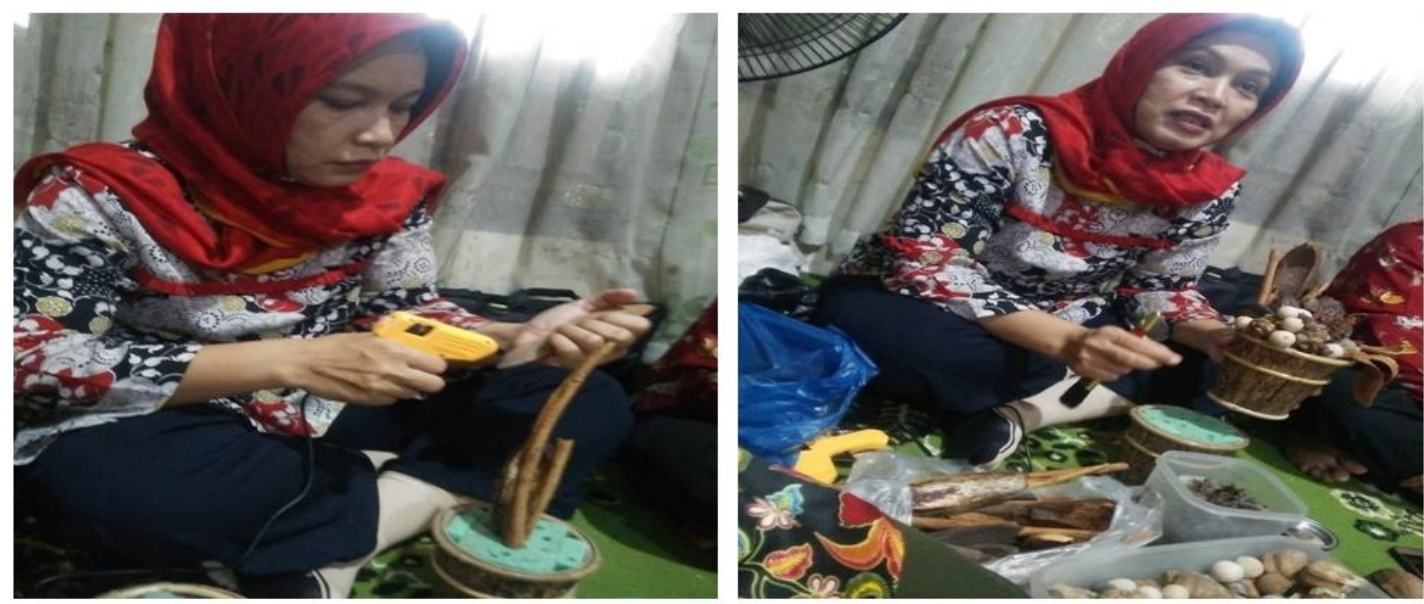

Gambar 3. Proses menata bijian dan rempah kering ke atas pot bunga

Setelah proses penataan bijian dan rempah kering maka akan menghasilkan hiasan bunga kering seperti terlihat pada gambar 4 di bawah ini: 


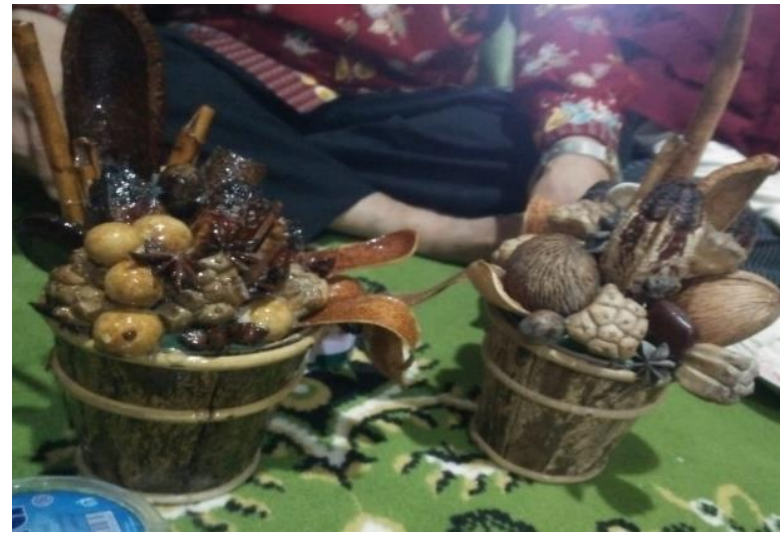

Gambar 4. Bunga kering yang sudah tersusun rapi

Agar bunga kering terlihat indah dan cantik maka proses selanjutnya adalah memberi vernis seperti terlihat pada Gambar 5.
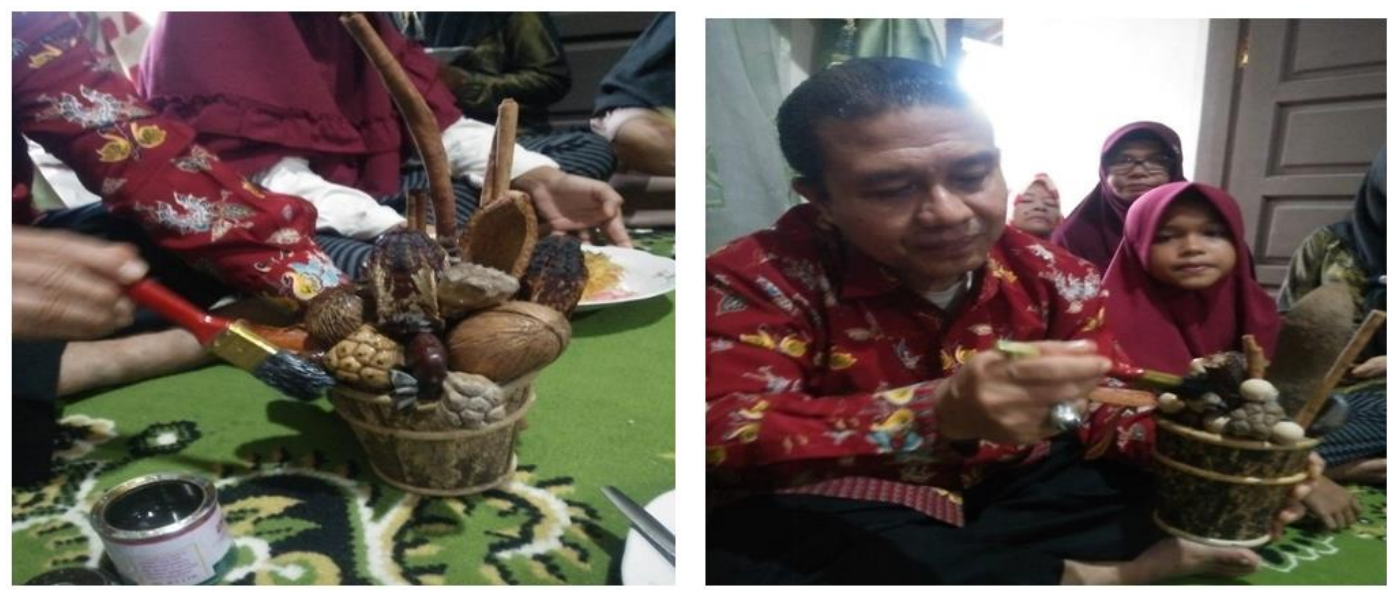

Gambar 5. Proses mempercantik bunga kering

Setelah vernis kering dengan menunggu beberapa saat sekitar 20 menit, hiasan bunga kering telah dapat dihasilkan. Contoh hasil bunga kering yang sudah jadi dapat dilihat pada gambar 6 di bawah ini: 

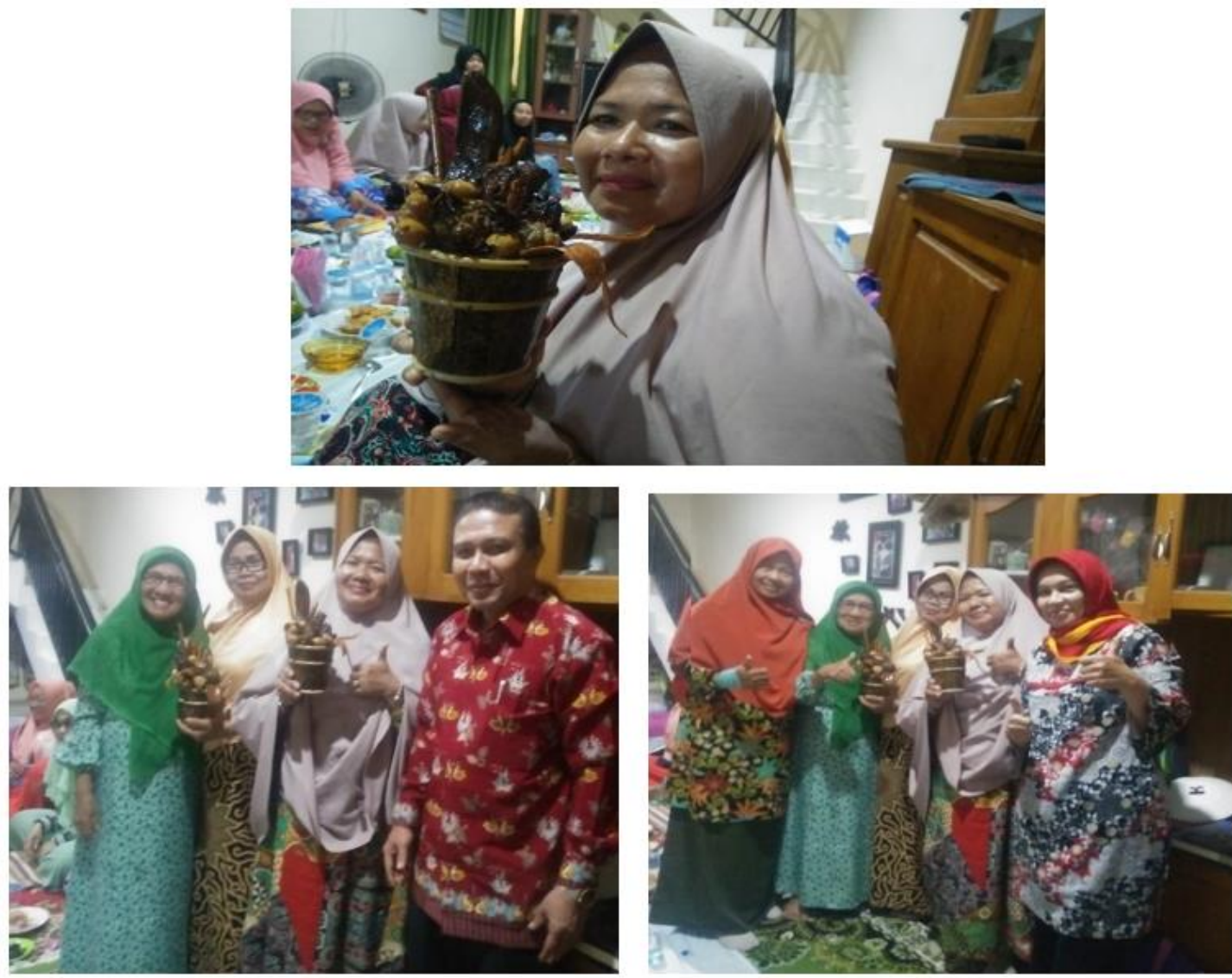

Gambar 6. Hasil rangkaian bunga kering

\section{Langkah Evaluasi Pelaksanaan Program dan Berkelanjutan Program di Lapangan setelah Kegiatan PKM selesai Dilaksanakan.}

Pada tahap ini dilakukan kegiatan evaluasi terhadap kreatifitas peserta yaitu ibu-ibu anggota PKK dalam memanfaatkan dan membuat aneka kreasi bunga kering, kesungguhan peserta, kendala-kendala yang dihadapi, kekurangan-kekurangan yang dirasakan dan kelemahankelamahan yang muncul beserta faktor-faktor yang mempengaruhinya. Diantara kendala yang dihadapi adalah waktu pelatihan masih kurang, belum banyak variasi kreatifitas lain dari bahan bekas dan masalah kesesuaian waktu. Kendala-kendala tersebut perlu menjadi perhatian kedepan. Pendampingan pada program PKM ini akan terus dilakukan terhadap peserta yang mengalami kesulitan dalam proses pembuatan bunga kering. Bila program pengabdian ini sukses dilaksanakan, tim akan menjalankan program ini secara berkelanjutan.

\section{KESIMPULAN}

Program pengabdian kepada masyarakat ini telah dilaksanakan dengan baik, peserta pelatihan sekitar 25 orang terdiri dari arisan ibu-ibu PKK dalam rentang usia yang bervariasi antara 25-60 Tahun. Kegiatan pelatihan keterampilan merangkai aneka kreasi bunga kering bertempat di rumah ibu Elly yang beralamat di Komplek Bungo Bumi Indah Blok A No. 2 RT 001, RW 012, Kelurahan Bungo Pasang. Ibu-ibu anggota PKK sangat antusias mengikuti kegiatan ini dari awal hingga selesai. Rasa ingin tahu peserta untuk membuat rangkaian bunga kering sangat besar ditunjukkan dengan banyaknya pertanyaan dari peserta selama kegiatan berlangsung, hal ini sangat baik untuk menambah pemahaman dan motivasi peserta dalam menekuni usaha 
pembuatan bunga kering. Tim pengabdian berhasil membuat rangkaian bunga kering dan langsung dibeli oleh peserta yang tertarik dan uangnya disumbangkan ke kas sosial PKK.

Saran yang dapat kami berikan dari kegiatan pengabdian ini adalah hendaknya peserta dapat mencoba secara langsung membuat rangkaian bunga kering ini sehingga manfaat kegiatan ini dapat dirasakan, kalaupun tidak untuk dijual minimal untuk hiasan rumah sendiri. Peran perguruan tinggi dalam memberikan pelatihan dan ide-ide kreatif baru sangat diharapkan oleh masyarakat pada masa yang akan datang, sehingga diharapkan kegiatan pengabdian ini dapat berkelanjutan. STKIP PGRI Sumatera Barat sangat mendukung kegiatan ini dengan memberikan surat tugas bagi dosen sebagai salah satu kewajiban tri dharma dan masuk dalam bagian beban kerja dosen (BKD) semester berjalan.

\section{UCAPAN TERIMAKASIH}

Terima kasih disampaikan kepada pimpinan institusi STKIP PGRI Sumatera Barat yang telah memberikan dukungan untuk melaksanakan kegiatan pengabdian mandiri ini. Terima kasih juga disampaikan kepada ibu-ibu PKK Komplek Bungo Bumi Indah RT 001 RW 012 Kelurahan Bungo Pasang, atas kerjasamanya sehingga terlaksananya kegiatan pengabdian ini dengan baik.

\section{DAFTAR PUSTAKA}

BPS Kota Padang, Kecamatan Koto Tangah Dalam Angka 2018, Katalog, ISBN: 978-602-0712-093, 2018.

Hendro. (2011) Dasar-Dasar Kewirausahaan: Panduan bagi Mahasiswa untuk Mengenal, Memahami, dan Memasuki Dunia Bisnis. Jakarta: Erlangga.

Saiman, L. (2014) Kewirausahaan: Teori, Praktik dan Kasus-Kasus. Jakarta: Salemba Empat.

Sukidjo. (2012) 'Peran Pendidikan Kewirausahaan dalam Pemberdayaan Masyarakat Miskin Indonesia.', Jurnal Economia, 8(1).

Suparyanto (2013) Kewirausahaan: Konsep dan Realita pada Usaha Kecil. Bandung.: Alfabeta.

Widjajanti, K. (2011) 'Model Pemberdayaan Masyarakat. Jurnal Ekonomi Pembangunan. Jurnal Ekonomi Pembangunan.', 12(1).

Wijatno, S. (2009) Pengantar Entrepreneurship. Jakarta: Gramedia Widiasarana. 